\title{
EKSPRESI BAHASA DAN PERSPEKTIF PADA BERITA PILPRES 2019 DI MEDIA ONLINEDETIK.COM
}

\author{
FARIDA YUFARLINA ROSITA', DWI KURNIASIH ${ }^{2}$ \\ IAIN Surakarta \\ fyrosita@gmail.com', dwikurniasih445@gmail.com²
}

Pertama Diterima 23 Maret 2018

Bukti Akhir Diterima 27 September 2019

\begin{abstract}
Abstrak
Tujuan dari penelitian ini adalah untuk mengkaji ekspresi bahasa pada berita pilpres 2019 di media online detik.com.Kajian yang digunakan dalam penelitian ini adalah analisis wacana.Penelitian ini menggunakan metode deskriptif kualitatif untuk mendeskripsikan data yang berupa wacana dalam berita.Teknik pengumpulan data yang digunakan adalah metode simak dengan teknik baca dan teknik catat, yaitu dengan menganalisis bentuk ekspresi bahasa pada pilihan kata yang terdapat dalam media online detik.com.Hasil penelitian menunjukkan bentuk pilihan kata meliputi, nilai ekspresimental, yakni pola klasifikasi, proses leksikal (generalisasi), proses leksikal (kelebihan leksikal), kata-kata ideologis, relasi makna yang ideologis, dan metafora; nilai rasional, yakni ekspresi eufemisme dan kata 'formal' dan 'informal yang mencolok; serta nilai ekspresif. Berdasarkan analisis perspektif terhadap wacana berita Pilpres 2019 pada media online detik.com tidak ditemukan data yang berkaitan dengan perspektif promasyarakat, 2 data yang propemerintah, dan 3 data netral.
\end{abstract}

Kata kunci: ekspresi bahasa, perspektif, analisis wacana, detik.com

\begin{abstract}
The purpose of this study is to examine the language expression in the 2019 presidential election news in detik.com online media. The study used in this study is discourse analysis. This study uses descriptive qualitative methods to describe data in the form of discourse in the news. The data collection technique used is the method of reading with reading techniques and note taking techniques, namely by analyzing the forms of language expression on word choices contained in detik.com online media. The results showed that the choice of words included expressive values, namely classification patterns, lexical processes (generalizations), lexical processes (lexical advantages), ideological words, ideological relations of meaning, and metaphors; rational values, namely expressions of euphemisms and the words' formal 'and' informal striking; and expressive value. Based on an analysis of the perspective of the 2019 Presidential Election news discourse on detik.com online media, there was no data related to the community's perspective, 2 government data, and 3 neutral data.
\end{abstract}

Keywords: language expression, perspective, discourse analysis, detik.com

\section{PENDAHULUAN}

Saat berlangsung kegiatan komunikasi, manusia secara tidak sadar telah memproduksi ujaran lisan atau tulisan.Komunikasi terjadi apabila orang yang terlibat dalam komunikasi atau komunikan melakukan kegiatan memperhatikan, melihat, dan mendengar seseorang yang diajak sebagai lawan berkomunikasi melalui tuturan atau suatu ujaran. Hal tersebut sesuai dengan yang disampaikan oleh Mulyana (2009: 69-71) bahwa terdapat 5 (lima) unsur yang berkaitan dalam sebuah komunikasi, yaitu sender (pengirim), message (pesan), channel (saluran), receiver (penerima), dan effect (efek/hasil). Hal tersebut jelas bahwa komunikasi akan berjalan dengan baik jika kelima unsur tersebut ada dalam sebuah konteks komunikasi.

Komunikasi dilakukan manusia untuk berhubungan dengan orang lain. Cara manusia berkomunikasi adalah dengan menggunakan bahasa sebagai perantara.Bahkan, hampir seluruh aktivitas manusia tidak dapat dilepaskan dari kegiatan menggunakan bahasa.Bahasa merupakan salah satu alat penting yang dimiliki manusia dalam mengembangkan kebudayaan atau peradabannya. Dalam menggunakan bahasa dalam komunikasi, makna yang diekspresikan oleh tuturan akan selalu dipertimbangkan oleh penutur dan lawan tutur. Untuk itu seorang penutur harus mengomunikasikan tuturan dengan jelas agar dapat dipahami oleh lawan atau mitra tuturnya. Berbagai cara agar informasi yang ingin dikemukakan dapat dipahami oleh lawan tuturnya kurang lebih sama dengan apa yang dimaksudkannya (Wijana, 2015:1-2).

Kartomihardjo (dalam Wati, 2014: 11-12) menjelaskan bahwa masyarakat sebagai komunitas pemakai bahasa, secara sadar atau tidak, menggunakan bahasa yang hidup dan digunakan dalam masyarakat.Hal tersebut karena bahasa adalah sebuah ekspresi sosial, dimana dengan bahasa, manusia dapat dengan mudah 
mengekspresikan kebutuhan pokoknya.Bahasa berita tentu tidak lepas dari konteks. Menurut Sobur (2009: 56), konteks memasukkan semua situasi dan hal yang berada di luar teks dan mempengaruhi pemakaian bahasa

Berita merupakan informasi yang memiliki nilai kebenaran dan azas manfaat. Nilai benar dan kebenaran serta azas manfaat, mutlak dipahami oleh wartawan atau orang-orang yang disebut insan pers. Hal ini karena apabila informasi yang disampaikan mengandung ketidakbenaran, fitnah atau tidak memiliki azas manfaat, niscaya informasi yang disampaikan tidak bisa dimasukkan kategori berita melainkan isu. Berita sebagai media komunikasi yang digunakan ketika dekat dengan pelaksanaan pemilu adalah yang berkaitan dengan kampanye.Kampanye disebutkan oleh Januru (2016: 182) sebagai sebuah strategi politik yang dilakukan oleh para elit politik.

Penelitian yang relevan terkait analisis wacana berita pernah dilakukan Khuriyati (2013) dengan judul Analisis Wacana Terhadap Teks Berita Tuntutan Pembubaran FPI Pada SKH Kompas Edisi Februari 2012. Tujuan penelitian ini adalah bagaimana Surat Kabar Harian Kompas mengembangkan wacana tuntutan pembubaran FPI.

Analisis wacana dapat memberikan gambaran kepada khalayak tentang apa yang ditampilkan oleh Kompas mengenai pemberitaan tentang pembubaran FPI. Dari wacana ini ditemukan ideologi Harian Kompas yang memiliki karakter dan latar belakang tersendiri dalam memproduksi sebuah berita.Hal ini dilatarbelakangi oleh berbagai motif, di antaranya, politik, ekonomi, dan agama.

Dari penelitian analisis berita wacana ini, ditemukan bahwa pemberitaan pada Surat Kabar Kompas terkesan berhati-hati.Hal ini dapat dilihat dalam beberapa judul berita yang ditampilkannya.Tidak hanya FPI yang dibubarkan, tetapi semua organisasi kemasyarakatan yang bertindak anarkis juga disebutkan.

Penelitian ini memiliki relevansi denganpenelitian yang dilakukan oleh Wati (2014) dengan judul Analisis Wacana Kritis Berita Sosial dan Politik Surat Kabar Kedaulatan Rakyat.Tujuan penelitian ini adalah untuk mengetahui ekspresi bahasa wacana berita sosial dan politik pada Surat Kabar Kedaulatan Rakyat September 2012 dan mengetahui perspektif wacana berita.Bentuk dari ekspresi bahasa wacana berita yang diperoleh dari penelitian ini adalah modalitas dan metafora.Perspektif yang didapati adalah propemerintah, promasyarakat, dan netral.

Penelitian serupa lainnya dilakukan oleh Kuswandari, dkk (2017). Penelitian tersebut berjudul Analisis Wacana: Representasi Pendidikan Indonesia pada Berita Online Detik.com. Dalam penelitian tersebut, Kuswandari, dkk memiliki tujuan untuk menjelaskan tema, proses terbentuknya struktur wacana berita online detik.com dan mengetahui upaya media tersebut dalam mengemas berita pendidikan Indonesia. Dalam penelitian tersebut, ditunjukkan bahwa analisis framing berita online detik.com adalah penonjolan penempatan headline. Bentuk pengulangan, pemakaian gambar, foto, grafis, dan data pendukung memperkuat penonjolan isu yang diangkat untuk menggambarkan informasi dan peristiwa yang diberikan.

Persamaan penelitian tersebut dengan penelitian ini adalah kedua penelitian ini sama-sama memiliki objek penelitian berita dalam media online.Akan tetapi, kedua penelitian ini memiliki perbedaan.Kuswandari melihat representasi pemberitaan, sedangkan penelitian ini melihat ekspresi bahasa dan perspektif yang dimunculkan dalam berita pada media online tersebut.

Wacana merupakan rekaman kebahasaan yang utuh tentang peristiwa komunikasi (Setiawan, 2012: 2). Disampaikan oleh ahli lain, bahwa wacana adalah komunikasi kebahasaan yang terlibat sebagai sebuah pertukaran di antara pembicara dan pendengar, sebagai sebuah aktivitas personal di mana bentuknya ditentukan oleh tujuan sosialnya (Hawtan dalam Badara, 2012:16).

Analisis wacana adalah istilah umum yang dipakai dalam banyak disiplin ilmu.Meskipun ada gradasi yang besar dari berbagai definisi, titik singgungnya adalah analisis wacana berhubungan dengan studi mengenai bahasa ataupun pemakaian bahasa (Eriyanto, 2001:3-4).Dalam analisis wacana, bahasa sebagai unit pengamat utama.Hal semacam ini dimungkinkan karena yang menjadi sorotan utama dalam analisis wacana adalah perepresentasian seseorang, kelompok, atau semua yang ditampilkan melalui bahasa (Badara, 2012:185).Ditambahkan oleh Badudu (dalam Badara, 2012:16), wacana merupakan rentetan kalimat yang menghubungkan proporsi yang satu dengan yang lainnya, membentuk satu kesatuan, sehingga terbentuklah makna yang serasi di antara kalimat-kalimat tersebut.Berdasarkan pendapat beberapa ahli tersebut, dapat disimpulkan bahwa wacana dapat disebut juga dengan kesatuan bahasa yang terlengkap dan tertinggi atau terbesar di atas kalimat atau klausa dengan koherensi dan kohesi yang tinggi dan berkesinambungan yang mampu mempunyai awal dan akhir yang nyata, disampaikan secara lisan atau tertulis.

Wacana melihat bahasa selalu terlibat dalam hubungan kekuasaan.Oleh karena memakai perspektif kritis, analisis wacana kategori ini disebut juga dengan analisis wacana kritis (critical discourse analysis).Analisis wacana kritis (AWK) didefinisikan sebagai upaya untuk menjelaskan suatu teks pada 
fenemona sosial untuk mengetahui kepentingan yang termuat didalamnya.Fungsi analis wacana kritis bagi masyarakat adalah memberikan kesadaran nyata atas peran mereka di masyarakat.Pemikiran ini bersumber dari bahwa ilmu itu "value-free".

Bahasa yang digunakan dalam suatu wacana berita dalam surat kabar atau di media-media berita daring atau online termasuk dalam kategori bahasa transaksional yang memiliki karakteristik dan lebih berorientasi pada penyampaian pesan secara efektif (Brown \& Yule dalam Badara, 2012:24). Sementara itu, menurut Suroso (dalam Wati, 2014: 32), seorang jurnalis atau wartawan dalam melaporkan suatu berita memandang dari ekspresi-ekspresi yang diyakini.

Ditinjau dari segi ragam bahasa, bahasa berita merupakan bagian dari bahasa jurnalistik atau dapat disebut dengan bahasa komunikasi massa, yaitu gaya bahasa yang digunakan dalam tulisan dan media massa, termasuk surat kabar atau berita-berita yang beredar melalui media sosial di internet. Ditinjau dari sifatnya, ekspresi bahasa dalam wacana berita mirip dengan bahasa jurnalistik.Ekspresi ini dibagi menjadi dua, yaitu komunikatif dan ekspresif.Komunikatif berarti sifat ekspresi yang langsung menjamah materi atau langsung menuju ke pokok persoalaan, tidak mengagung-agungkan yang menyebabkan berbunga-bunga, tidak berteletele, dan tanpa basa-basi. Sementara itu, ekspresi spesifik memiliki gaya penulisan tersendiri secara sederhana kata-kata jelas mudah dimengerti kalangan umum, memiliki sifat yang lebih condong ke bahasa jurnalistik dari pada wacana berita. Khusus penggunaan bahasa pada judul wacana berita, umumnya mengabaikan kaidah bahasa meskipun tetap mengandung pemadatan yang mencerminkan isi berita.

Terdapat tiga pandangan dalam sebuah ekspresi bahasa wacana berita.Pertama, pandangan promasyarakat, pandangan ini adalah sudut pandang ketika melihat dan melaporkan suatu peristiwa yang didasari oleh nilai, keyakinan, ide-ide, serta pandangan dari masyarakat.Kedua, propemerintah.Pandangan ini adalah pandangan dari sudut pandang yang melihat dan melaporkan sudut pandang peristiwa yang didasari oleh nilai-nilai, keyakinan, ide-ide, dan pandangan pemerintah.Ketiga, pandangan netral adalah pandangan yang melihat dan melaporkan suatu peristiwa yang didasari oleh sikap wartawan yang akomodatif dan netral terhadap semua pihak yang terlibat dalam wacana berita.Sikap ini berupa penilaian sikap memihak atau mendukung, sikap tidak memihak tidak mendukung, dan sikap netral tidak memihak atau tidak mendukung.

Berdasarkan pemaparan di atas, maka penelitian ini mengkaji tentang ekspresi bahasa dan perspektif berita pilpres 2019 pada media online detik.com.

\section{METOTE PENELITIAN}

Penelitian ini menggunakan metode deskriptif kualitatif. Deskriptif kualitatif merupakan metode yang digunakan untuk mendeskripsikan data secara nyata dan apa adanya sesuai dengan fakta yang diperoleh di lapangan. Subjek dalam penelitian ini adalah berita Pilpres 2019 di media online.Subjek ini diambil melalui media online, yaitu www.detik.com.Data dalam penelitian ini berupa wacana berita Pilpres 2019.Objek penelitian ini adalah bentuk-bentuk ekspresi bahasa wacana berita.

Dalam penelitian ini, wujud data berupa teks pemberitaan Pilpres 2019 secara keseluruhan dan kalimatkalimat yang terdapat dalam teks.Wujud data pertama yang berupa kalimat-kalimat digunakan untuk mengungkap objek penelitian berupa bentuk-bentuk ekspresi bahasa. Wujud data kedua berupa teks berita sosial dan politik digunakan untuk mengungkap objek penelitian perspektif pemberitaan.Sumber data ini adalah tertulis berupa bahasa tulis yang terdapat dalam media online.

Pengumpulan data dalam penelitian ini menggunakan metode simak dengan teknik baca dan teknik catat.Teknik analisis data yang digunakan dalam penelitian ini adalah teknik deskriptif kualitatif.Langkahnya adalah 1) mendeskripsikan bentuk-bentuk ekspresi bahasa wacana pemberitaan Pilpres 2019, 2) mengelompokkan data-data berdasarkan bentuk-bentuk ekspresi bahasa, 3) mendeskripsikan perspektif wacana berita tersebut.

\section{HASIL PENELITIAN DAN PEMBAHASAN}

Data-data yang diperoleh dan dibahas dalam penelitian ini mencakup permasalahan tentang bentukbentuk ekspresi bahasa dan perspektif yang muncul dalam wacana pemberitaan Pilpres 2019. 


\section{Bentuk Ekspresi Bahasa Berita Pilpres pada Media Online Detik.com}

Berikut adalah data pemberitaan Pilpres 2019 melalui media online yaitu detik.com dengan lima topik yang berbeda, yaitu (a) Hoaks Ratna Sarumpaet, (b) Debat Capres Keempat Soal TNI, (c) Petugas KPPS, (d) Input Data, dan (e) Setan Gundul.Data pemberitaan Pilpres 2019 pada media online ini terdiri atas 5 (lima) topik yang terdapat dalam tabel 1 berikut.

Tabel 1. Topik dan Judul Berita di Media Online Detik.com

\begin{tabular}{|l|l|}
\hline \multicolumn{1}{|c|}{ Topik } & \multicolumn{1}{c|}{ Judul } \\
\hline Hoaks Ratna Sarumpaet & $\begin{array}{l}\text { Drama Ratna Sarumpaet Bikin Prabowo Blunder dan Elektoral } \\
\text { Negatif }\end{array}$ \\
\hline $\begin{array}{l}\text { Debat Capres Keempat } \\
\text { Soal TNI }\end{array}$ & Jokowi Sangat Percaya TNI, Prabowo Lebih TNI dari Banyak TNI \\
\hline Petugas KPPS & $\begin{array}{l}\text { Soal Hoax Petugas KPPS Tewas Diracun, KPU: Itu Tak Pantas } \\
\text { Dibuat }\end{array}$ \\
\hline Input Data & Salah Input Data, 56 TPS di Kabupaten Malang Gelar Hitung Ulang \\
\hline Setan Gundul & SMS Bukan dari Setan Gundul Klaim BPN Menang \\
\hline
\end{tabular}

Bentuk ekspresi bahasa yang akan dikaji adalah dari segi pilihan kata. Pilihan kata terbagi dalam tiga bentuk nilai, yaitu nilai eksperiensial, nilai relasional, dan nilai ekspresif.Berikut data pilihan kata dari mediaonline detik.com.

Tabel 2. Data Ekspresi Bahasa dari Segi Pilihan Kata

\begin{tabular}{|c|c|c|c|c|}
\hline \multirow[b]{2}{*}{ No. } & \multirow[b]{2}{*}{ Data } & \multicolumn{3}{|c|}{ Nilai } \\
\hline & & $\begin{array}{c}\text { Eksperiensi } \\
\text { al }\end{array}$ & Relasional & Ekspresif \\
\hline$d / 1$ & Drama & $\sqrt{ }$ & & \\
\hline $\mathrm{d} / 2$ & Terbongkar & $\sqrt{ }$ & & \\
\hline $\mathrm{d} / \mathbf{3}$ & Founder & & $\sqrt{ }$ & \\
\hline$d / 4$ & Skandal & $\sqrt{ }$ & & \\
\hline$d / 5$ & Tak termaafkan & & & $\sqrt{ }$ \\
\hline$d / 6$ & Kartu merah & $\sqrt{ }$ & & \\
\hline $\mathrm{d} / 7$ & Blunder & $\sqrt{ }$ & & \\
\hline $\mathrm{d} / \mathbf{8}$ & Jurkamnas & $\sqrt{ }$ & & \\
\hline$d / 9$ & Elektoral negatif & & & $\sqrt{ }$ \\
\hline $\mathrm{d} / \mathbf{1 0}$ & Mudah dikecoh & & & $\sqrt{ }$ \\
\hline $\mathrm{d} / \mathbf{1 1}$ & Senjata politik & $\sqrt{ }$ & & \\
\hline $\mathrm{d} / \mathbf{1 2}$ & Menyerang & $\sqrt{ }$ & & \\
\hline$d / 13$ & Check dan recheck & & $\sqrt{ }$ & \\
\hline$d / 14$ & Gimana & & $\sqrt{ }$ & \\
\hline$d / 15$ & Terlalu mudah dikecoh & & & $\sqrt{ }$ \\
\hline $\mathrm{d} / \mathbf{1 6}$ & Tak cukup & & $\sqrt{ }$ & \\
\hline $\mathrm{d} / \mathbf{1 7}$ & Berjanji & & $\sqrt{ }$ & \\
\hline $\mathrm{d} / \mathbf{1 8}$ & Meng-attack & & $\sqrt{ }$ & \\
\hline$d / 19$ & Lawannya & $\sqrt{ }$ & & \\
\hline $\mathrm{d} / \mathbf{2 0}$ & Fact verification & & $\sqrt{ }$ & \\
\hline $\mathrm{d} / \mathbf{2 1}$ & Menaruh penuh percaya & & & $\sqrt{ }$ \\
\hline $\mathrm{d} / \mathbf{2 2}$ & Menegaskan & & $\sqrt{ }$ & \\
\hline$d / 23$ & Pak & $\sqrt{ }$ & & \\
\hline$d / 24$ & Ketua Umum Gerindra & $\sqrt{ }$ & & \\
\hline$d / 25$ & Tidak percaya & & & $\sqrt{ }$ \\
\hline $\mathrm{d} / 26$ & Pak Prabowo & $\sqrt{ }$ & & \\
\hline$d / 27$ & Lihat dan cek & $\sqrt{ }$ & & \\
\hline $\mathrm{d} / 28$ & Penasihat militer & $\sqrt{ }$ & & \\
\hline$d / 29$ & Nice guy & & $\sqrt{ }$ & \\
\hline $\mathrm{d} / \mathbf{3 0}$ & Sky drone fighter & & $\sqrt{ }$ & \\
\hline $\mathrm{d} / \mathbf{3 1}$ & Diplomasi & $\sqrt{ }$ & & \\
\hline$d / 32$ & Nggak & & $\sqrt{ }$ & \\
\hline $\mathrm{d} / \mathbf{3 3}$ & Komisioner KPU & $\sqrt{ }$ & & \\
\hline $\mathrm{d} / \mathbf{3 4}$ & Menelan & $\sqrt{ }$ & & \\
\hline$d / 35$ & Dikonfirmasi & $\sqrt{ }$ & & \\
\hline
\end{tabular}




\begin{tabular}{|l|l|c|c|c|}
\hline $\mathbf{d} / \mathbf{3 6}$ & Cari tahu dulu dan tabayun & $\sqrt{ }$ & & \\
\hline $\mathbf{d} / \mathbf{3 7}$ & Menggelar & $\sqrt{ }$ & & \\
\hline $\mathbf{d} / \mathbf{3 8}$ & Ditelusuri dan dibuka & $\sqrt{ }$ & & \\
\hline $\mathbf{d} / \mathbf{3 9}$ & Setan gundul membisikkan & $\sqrt{ }$ & & \\
\hline $\mathbf{d} / \mathbf{4 0}$ & Sesat & & & $\sqrt{ }$ \\
\hline $\mathbf{d} / \mathbf{4 1}$ & Profesor & $\sqrt{ }$ & & \\
\hline $\mathbf{d} / \mathbf{4 2}$ & Otak & $\sqrt{ }$ & & \\
\hline $\mathbf{d} / \mathbf{4 3}$ & Meng-collect & & $\sqrt{ }$ & \\
\hline $\mathbf{d} / \mathbf{4 4}$ & Pak Prabowo & $\sqrt{ }$ & & \\
\hline $\mathbf{d} / \mathbf{4 5}$ & Channel & & $\sqrt{ }$ & \\
\hline $\mathbf{d} / \mathbf{4 6}$ & Relawan & $\sqrt{ }$ & & $\sqrt{ }$ \\
\hline $\mathbf{d} / \mathbf{4 7}$ & Menyesatkan & & $\mathbf{2 6}$ & $\mathbf{1 3}$ \\
\hline \multicolumn{1}{|c|}{ Jumlah } & & \\
\hline
\end{tabular}

\section{Nilai Eksperiensial}

Dalam media ini, terdapat 26 nilai eksperiensial yang dapat dideskripsikan. Nilai eksperiensial berhubungan dengan nilai, pengetahuan, dan keyakinan.

\section{Pola Klasifikasi Teks}

Pola-pola klasifikasi teks digunakan untuk menggambarkan realitas tertentu.Berikut pola klasifikasi teks yang tergambar dalam teks berita.

Drama penganiayaan Ratna Sarumpaet terbongkar sudah.Pengakuan atas kebohongan yang diceritakan sembari terisak itu pun berujung permintaan maaf dari capres nomor urut 02 sekaligus Ketua Umum Partai Gerindra, Prabowo Subianto. (detik.com)

Pada penggalan berita tersebut, penghasil teks yang disampaikan oleh penulis atau redaksi, mengatakan bahwa Ratna Sarumpaet melakukan aksi drama.Drama adalah istilah yang biasanya ada dalam sebuah karya sastra.Drama digunakan untuk mengklasifikasikan atau menggolongkan kegiatan yang dilakukan seseorang atau sekelompok orang berdasarkan cerita atau kisah, terutama yang melibatkan konflik atau emosi, yang khusus disusun untuk pertunjukan teater.Hal yang dipaparkan dalam berita adalah saat Ratna Sarumpaet mengaku dianiaya oleh sekelompok orang hingga wajahnya menjadi lebam. Akan tetapi, pengakuan tersebut ternyata hanya bohong belaka. Penulis, dalam hal ini adalah wartawan detik.com melakukan penegasan dengan menggolongkan Ratna Sarumpaet melakukan aksidramayang sebelumnya membuat heboh negara.Penghasil teks berusaha membangun citra Ratna Sarumpaet melakukan hal yang tidak tepat atau salah.

Data kutipan berita ini juga termasuk dalam pola klasifikasi teks.

Founder Lingkaran Survei Indonesia, Denny JA, menyebut kebohongan tersebut sudah bertaraf skandal. Drama penganiayaan oleh Ratna akan selalu dikenang dan tak termaafkan (detik.com)

Penghasil teks yang disampaikan pada penggalan berita tersebut, seperti yang dikutip dari ungkapan Denny JA, mengatakan bahwa kebohongan Ratna Sarumpaet sudah bertaraf skandal.Skandal diistilahkan sebagai sebuah insiden yang dipublikasikan atau diumumkan yang melibatkan dugaan pelanggaran, aib, atau pencabulan moral.Skandal yang dipaparkan dalam berita adalah saat kebohongan Ratna Sarumpaet yang merupakan aib menjadi berita heboh dan tersebar ke seluruh pelosok negeri. Penulis, dalam hal ini adalah wartawan detik.com melakukan penegasan dengan menggolongkan Ratna Sarumpaet melakukan aksi yang bertaraf skandal. Penghasil teks berusaha membangun citra Ratna Sarumpaet melakukan hal yang tidak tepat atau salah.

\section{Proses Leksikal (Generalisasi)}

Berikut adalah wujud penggunaan pilihan kata dengan proses generalisasi.

"Pak Jokowi, tolong penasihat militernya. Bukan saya tidak percaya sama TNI. Kapal selam berapa yang kita miliki, jenisnya berapa, kemampuannya berapa, pesawat berapa, kita negara seluas Eropa berapa, sky drone fighter kita punya peluru kendalinya berapa Pak. Diplomasi kalau hanya senyum-senyum menjadi nice guy ya... Begitu-begitu saja Pak. Kalau ada armada asing masuk ke laut kita, apa yang kita bisa buat? Jadi bukan saya tidak percaya saya ini TNI Pak, saya pertaruhkan nyawa di TNI, saya lebih TNI dari banyak TNI," jelas eks Danjen Kopassus ini. 
Penggunaan kata 'Pak' oleh Prabowo yang kemudian dikutip oleh merdeka.com dalam penggalan berita tersebut merupakan generalisasi.Kata 'Pak' dalam penggalan dalam berita di atas merupakan perluasan makna.'Pak' atau 'Bapak' yang semula bermakna orangtua pria yang lazimya menjadi kepala keluarga dan pencari nafkah.Namun makna kata 'Pak' tersebut kemudian diperluas, sehingga kata 'Pak' pada kalimat adalah sebutan bagi pria yang dianggap umurnya lebih tua atau dihormati.Kesan yang timbul dalam penggalan berita di atas adalah Prabowo menghormati Jokowi sebagai tokoh yang luar biasa atau tokoh yang disegani.

\section{Proses Leksikal (Kelebihan Leksikal)}

Proses leksikal atau proses pemilihan kata-kata dalam sebuah wacana adalah penting sebagai pembentuk ideologi. Proses kelebihan wacana (over lexicalization) merupakan salah satu bentuk leksikal yang menggunakan lebih dari satu kata yang memiliki makna hampir sama atau mirip. Berikut ini pilihan kata kelebihan leksikal pada teks berita di detik.com.

Apalagi, kata Denny, kebohongan tersebut kemudian justru dijadikan senjata politik untuk menyerang petahana, Presiden Joko Widodo (Jokowi). Padahal belum ada konfirmasidan check and recheck terhadap informasi yang didapat dari Ratna itu.

Dalam penggalan teks tersebut, ada beberapa pilihan kata yang memiliki makna mirip digunakan bersamaan dalam menggambarkan suatu kejadian. Penghasil teks mengutip pendapat narasumber, menyampaikan bahwa kebohongan Ratna Sarumpaet atas kasus penyerangan dijadikan senjata politik untuk menyerang Capres Joko Widodo, padahal belum dilakukan konfirmasi, check, dan recheck. Ketiga pilihan kata tersebut memiliki makna yang mirip.Konfirmasi adalah penegasan, pembenaran. Check yang dalam bahasa Indonesia berarti cek memiliki arti mencocokkan kembali benar tidaknya, pemeriksaan. Recheck berarti mengecek atau memeriksa kembali.

Berikut ini juga merupakan contoh penggunaan bahasa dengan kelebihan leksikal.

"Beliau adalah koordinatornya, otaknya nih yang mengumpulkan, meng-collect semua data C1, baik dari relawan dan dari lain-lainnya untuk Badan Pemenangan Pak Prabowo," kata Vasco dalam video yang diunggah di channel YouTube miliknya, Macan Idealis.

Kata koordinator dan otak dalam kutipan berita tersebut mengacu pada subjek yang sama. Yang dimaksud dengan koordinator adalah orang yang mengoordinasi, sedangkan otak dalam kutipan tersebut berarti orang yang menjadi tokoh utama. Maka, otak dan koordinator tersebut adalah proses kelebihan leksikal yang digunakan untuk menegaskan sebuah berita.

\section{Relasi Makna yang Ideologis}

Dalam penulisan sebuah wacana berita, pilihan kata ideologis akan banyak dimunculkan oleh penghasil teks sebagai bentuk atau wujud ideologinya, termasuk relasi makna ideologis. Relasi makna berarti memiliki hubungan makna secara ideologis.Hal ini dapat dilihat dalam penggalan teks berikut ini.

"Beliau adalah koordinatornya, otaknya nih yang mengumpulkan, meng-collect semua data C1, baik dari relawan dan dari lain-lainnya untuk Badan Pemenangan Pak Prabowo," kata Vasco dalam video yang diunggah di channel YouTube miliknya, Macan Idealis.

Kata otak dan koordinator yang dimaksud oleh penghasil teks dengan mengutip pendapat narasumber memiliki relasi makna ideologis.Relasi makna ini berupa sinonim antara kata otak dan koordinator.Otak memiliki arti biang keladi, tokoh, atau seseorang yang menjadi kepala atau memimpin.Sementara itu, koordinator berarti orang yang melakukan koordinasi.Koordinator adalah orang yang mengatur suatu organisasi atau tindakan yang dilaksanakan sekelompok orang.

Selain itu, bentuk atau wujud lain dapat dilihat dalam penggalan berikut ini.

"Pesan KPU kepada masyarakat, harus cari tahu dulu, jangan terima semua berita dan apa yang dibaca, berita yang kaya begini kan harus dikonfirmasi dulu beritanya benar atau tidak.Kita harus cari tahu dulu.Zaman sekarang ini semua kita harus tabayun," pungkasnya.

Maksud oleh penghasil teks mengutip pendapat narasumber dengan kata cari tahu dan tabayun juga merupakan penjelasan atau penegasan sebuah wacana bahwa masyarakat seharusnya tidak menelan mentahmentah yang diterima.Harus dilakukan konfirmasi, mencari tahu kebenaran dan tabayun agar tidak mendapatkan informasi yang sesat.Beberapa pilihan kata tersebut memiliki relasi makna ideologis.Tabayun berasal dari bahasa Arab yang secara harfiah berarti pemahaman atau penjelasan.Pilihan kata cari tahu yang 
dimaksud dalam penggalan teks tersebut berarti mencari informasi, pemahaman, atau penjelasan atas benar tidaknya suatu berita.Maka, dua pilihan kata ini merupakan sinonim yang digunakan oleh penghasil teks dalam menjelaskan ideologinya.

Metafora

Penggunaan pilihan kata dengan metafora juga digunakan dalam pemberitaan Pilpres 2019 melalui media detik.com. Salah satu contohnya adalah sebagai berikut.

Vasco lalu bicara soal setan gundul yang disebut-sebut membisikkan Prabowo menang 62\%.Diketahui, 'setan gundul' jadi ramai diperbincangkan setelah Wasekjen Partai Demokrat

Andi Arief bicara di akun Twitter-nya.

Penggunaan metafora sebagai lukisan berdasarkan persamaan atau kelompok kata bukan dengan arti sebenarnya dalam penggalan teks tersebut adalah setan gundul dan membisikkan.Setan gundul merupakan sebuah istilah metafora yang tiba-tiba muncul pada proses pemilu 2019. Pilihan kata setan gundul banyak digunakan diawali dengan pemberitaan bahwa Capres Prabowo menang 62\% pada pilpres 2019.Jika dilihat pada arti kata sebenarnya, setan adalah roh jahat, sedangkan gundul adalah tidak berambut.Setan gundul yang dimaksud adalah orang atau manusia yang berbuat jahat, bukan setan dalam arti sebenarnya.

\section{Nilai Relasional}

\section{Ekspresi Eufemisme}

Dalam menyampaikan sebuah teks, seseorang perlu memilih kata-kata untuk mengalihkan kesan tidak sopan. Pemilihan kata tersebut dapat dilakukan dengan penggunaan eufimisme.

"Kebohongan Ratna Sarumpaet ini sudah taraf skandal.Karena diucapkannya secara sengaja membuat efek kehebohan sebuah negara.Ibarat bola, ini dia sudah terkena kartu merah," kata Denny saat dihubungi detikcom, Kamis (4/10/2018).

"Seharusnya dia mendapatkan kartu merah tak hanya dari timses Prabowo, tapi juga dari aktivis pada umumnya, karena ini menjadi blunder dan menjadi contoh publik lebih luas," imbuhnya.

Dalam penggalan teks berita tersebut, dijelaskan bahwa karena kebohongannya, Ratna Sarumpaet seharusnya mendapat kartu merah. Ungkapan tersebut merupakan wujud ekspresi eufemisme yang dilakukan oleh penghasil teks.Kartu merahjika tidak mengalami eufemisme maka bisa dikatakan bahwa maksud ungkapan tersebut adalah hukuman untuk keluar dari tim. Penghasil teks bisa sajamelakukan eufemisme untuk menghindari persepsi negatif publik Ratna Sarumpaet.

\section{Kata-kata 'Formal' dan 'Informal' yang Mencolok}

Kata-kata formal ditunjukkan melalui pilihan kosakata asing dan kosakata ilmiah yang dapat mendatangkan nada formal.Berikut penggalan pemberitaan Pilpres 2019 melalui media sosial yang menggunakan kosakata asing dan kosakata ilmiah untuk menciptakan kesan formal.

Selain hal itu, ada beberapa kata asing lagi yang digunakan dengan tujuan menciptakan prestise sosial, yaitu sebagai berikut.

Founder Lingkaran Survei Indonesia, Denny JA, menyebut kebohongan tersebut sudah bertaraf skandal. Drama penganiayaan oleh Ratna akan selalu dikenang dan taktermaafkan. (detik.com)

Kata founder dalam penggalan berita tersebut memiliki padanan kata 'penemu' dalam Bahasa Indonesia.Dewasa ini, bagi sebagian orang, penggunaan Bahasa Asing dianggap memiliki nilai lebih tinggi dari pada bahasa Indonesia. Penggalan berita berikut ini juga menggunakan bahasa asing, yaitu check and recheck.Check and recheck adalah pilihan kata yang digunakan untuk mengganti kata 'mengecek' dan 'mengecek kembali'. Kata check and recheck dirasa lebih menunjukkan prestise sosial jika digunakan dalam kasus ini.

Apalagi, kata Denny, kebohongan tersebut kemudian justru dijadikan senjata politik untuk menyerang petahana, Presiden Joko Widodo (Jokowi). Padahal belum ada konfirmasi dan check and recheck terhadap informasi yang didapat dari Ratna itu. (detik.com)

Kata attack dalam penggalan berita tersebut memiliki padanan kata 'menyerang' dalam Bahasa Indonesia. Kata fact verification dapat dialihbahasakan ke bahasa Indonesia menjadi verifikasi kebenaran. Katakata tersebut dapat dilihat dalam kutipan berita berikut ini. 
"Tidak akan menjadikan informasi itu untuk meng-attack atau mengkritik lawannya sebelum itu diyakini info yang benar.Kalau tidak, ruang publik ini akan mudah dipengaruhi oleh mereka yang berbohong," tuturnya.

"Sekarang modal kita belajar, jangan lagi mudah percaya, meneruskan informasi apalagi menyerang sebelum ada factverification, check and rechecksecara memadai, kalau nggak, akan rawan ruang publik ini. Terlalu banyak kebohongan yang terlalu cepat diproduksi," pungkas Denny. (detik.com)

\section{Nilai Ekspresif}

Dalam wacana, nilai ekspresif menunjukkan ekspresi penghasil teks dalam memandang sebuah kejadian. Nilai ekspresif terwujud dalam dua jenis evaluasi, yaitu evaluasi positif dan evaluasi negatif.

"Efeknya, elektoral negatif terhadap Prabowo.Mengapa? Karena menunjukkan bahwa tim Prabowo ini mudah dikecoh ya," ujarnya.

Pilihan kata mudah dikecoh dalam penggalan teks tersebut digunakan oleh penghasil teks untuk memberikan evaluasi negatif terhadap tim Prabowo karena dirasa terlalu percaya dengan berita bohong yang disampaikan Ratna Sarumpaet. Evaluasi negatif terhadap sebuah kejadian juga digambarkan oleh penghasil teks diikuti dengan evaluasi positif pada kejadian yang sama. Berikut adalah penggalan teks berita pada detik.com.

Capres Jokowi dan Prabowo Subianto sama-sama menegaskan komitmennya kepada TNI.Jokowi menyebut dirinya menaruh penuh percaya pada.TNI dan Prabowo menegaskan sudah mempertaruhkan nyawanya untuk TNI.Menanggapi Prabowo, Jokowi menyebut Ketum Gerindra tersebut tidak percaya pada TNI. Jokowi yang sebagai warga sipil menyebut dirinya sangat percaya pada TNI.

Penghasil teks seolah memiliki ideologi yang jelas pada penggambaran nilai ekspresif dalam memandang kejadian tersebut.Digunakan pilihan kata menaruh percaya dan tidak percaya dalam satu waktu.Pilihan kata menaruh percaya dalam penggalan teks tersebut digunakan oleh penghasil teks untuk memberikan evaluasi positif kepada Joko Widodo, sementara pilihan kata tidak percaya digunakan untuk memberikan evaluasi negatif pada Prabowo Subianto.

\section{Perspektif WacanaBerita Pilpres pada Media Online Detik.com}

Analisis perspektif terhadap wacana berita Pilpres 2019 pada media online detik.com data berkaitan dengan perspektif promasyarakat, propemerintah, dan netral.Hal tersebut dalam dilihat dalam Tabel 3.

Tabel 3. Analisis Perspektif pada Media Online Detik.com

\begin{tabular}{|c|c|c|c|c|c|c|}
\hline \multirow[b]{2}{*}{$\begin{array}{l}\text { Kode } \\
\text { Data }\end{array}$} & \multirow[b]{2}{*}{ Media } & \multirow[b]{2}{*}{ Topik } & \multirow[b]{2}{*}{ Judul Berita } & \multicolumn{3}{|c|}{ Perspektif } \\
\hline & & & & $\begin{array}{c}\text { Pro } \\
\text { masyarak } \\
\text { at }\end{array}$ & $\begin{array}{c}\text { Pro } \\
\text { pemerintah }\end{array}$ & Netral \\
\hline $\mathrm{T} 1 / \mathrm{d}$ & \multirow{5}{*}{ 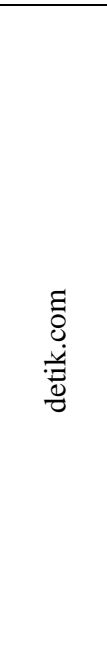 } & $\begin{array}{l}\text { Hoaks Ratna } \\
\text { Sarumpaet }\end{array}$ & $\begin{array}{l}\text { Drama Ratna Sarumpaet } \\
\text { Bikin Prabowo Blunder } \\
\text { dan Elektoral Negatif }\end{array}$ & & $\sqrt{ }$ & \\
\hline $\mathrm{T} 2 / \mathrm{d}$ & & $\begin{array}{l}\text { Debat Capres } \\
\text { Keempat Soal } \\
\text { TNI }\end{array}$ & $\begin{array}{l}\text { Jokowi Sangat Percaya } \\
\text { TNI, Prabowo Lebih TNI } \\
\text { dari Banyak TNI }\end{array}$ & & & $\sqrt{ }$ \\
\hline $\mathrm{T} 3 / \mathrm{d}$ & & Petugas KPPS & $\begin{array}{l}\text { Soal Hoax Petugas KPPS } \\
\text { Tewas Diracun, KPU: Itu } \\
\text { Tak Pantas Dibuat }\end{array}$ & & $\sqrt{ }$ & \\
\hline $\mathrm{T} 4 / \mathrm{d}$ & & Input Data & $\begin{array}{l}\text { Salah Input Data, } 56 \text { TPS di } \\
\text { Kabupaten Malang Gelar } \\
\text { Hitung Ulang }\end{array}$ & & & $\sqrt{ }$ \\
\hline $\mathrm{T} 5 / \mathrm{d}$ & & Setan Gundul & $\begin{array}{l}\text { SMS Bukan dari Setan } \\
\text { Gundul Klaim BPN Menang }\end{array}$ & & & $\sqrt{ }$ \\
\hline
\end{tabular}


Tabel tersebut menunjukkan bahwa analisis perspektif terhadap wacana berita Pilpres 2019 pada media online detik.com tidak ditemukan data berkaitan dengan perspektif promasyarakat, 2 data yang propemerintah, dan 3 data netral.

Perspektif propemerintah merupakan sudut pandang dalam melihat suatu peristiwa yang didasari oleh nilai-nilai keyakinan, ide-ide, dan pandangan pemerintah.Setiap wartawan dalam melaporkan suatu peristiwa dengan berdasarkan pesrpektif pro pemerintah memiliki sikap atau pandangan yang mendukung, memihak, dan senang terhadap tindakan yang dilakukan oleh pemerintah (Wati, 2014: 67). Namun sebaliknya akan berdampak buruk bagi sederetan pihak yang sedang berseteru atau berseberangan dengan pemerintah, sehingga akan menimbulkan sikap-sikap yang tidak mendukung, tidak memihak, bahkan cenderung benci terhadapat tindakan yang dilakukan pemerintah. Berikut ini adalah data yang menunjukan perspektif pro pemerintah.

Pada data (T1/d) dengan judul (Drama Ratna Sarumpaet Bikin Prabowo Blunder dan Elektoral Negatif) menunjukan sikap wartawan yang pro pemerintah.

"Drama penganiayaan Ratna Sarumpaet terbongkar sudah.Pengakuan atas kebohongan yang diceritakan sembari terisak itu pun berujung permintaan maaf dari capres nomor urut 02 sekaligus Ketua Umum Partai Gerindra, Prabowo Subianto.Founder Lingkaran Survei Indonesia, Denny JA, menyebut kebohongan tersebut sudah bertaraf skandal. Drama penganiayaan oleh Ratna akan selalu dikenang dan tak termaafkan. "Kebohongan Ratna Sarumpaet ini sudah taraf skandal.Karena diucapkannya secara sengaja membuat efek kehebohan sebuah negara.Ibarat bola, ini dia sudah terkena kartu merah," kata Denny saat dihubungi detikcom, Kamis (4/10/2018)."

Pada kutipan data di atas terdapat topik Hoaks Ratna Sarumpaet. Wartawan memilih topik tersebut yang secara tidak langsung telah mendukung penyelenggaraan Pilpres 2019 sekaligus menyayangkan kasus hoax yang menimpa Ratna Sarumpaet yang membuat kehebohan negara menjelang Pilpres 2019. Dari segi partisipan, Ratna Sarumpaet dan Founder Lingkaran Survei Indonesia, Denny JA menjadi fokus utama sebagai partisipan.Dilihat dari segi nada pemberitaan wartawan banyak membicarakan tentang efek dari kasus kebohongan Ratna Sarumpeat terhadap Paslon Prabowo-Sandi.

Pada data (T3/d) dengan judul (Soal Hoax Petugas KPPS Tewas Diracun, KPU: Itu Tak Pantas Dibuat) menunjukan sikap wartawan yang pro pemerintah.

"KPU mengatakan berita bohong (hoax) terkait adanya petugas KPPS yang tewas diracun tidak pantas dibuat.KPU berharap pelaku penyebar hoax itu bertobat dan diampuni dosanya.

"Semoga yang membuat hoax seperti ini diampuni oleh Allah SWT. Sama juga dengan yang di Bekasi, memberitakan orang meninggal sebelum waktunya padahal masih dirawat di rumah sakit, itu kan satu hal yang nggak pantas dibuat, menyebarkan hoax seperti itu. Makanya saya mau minta ampunan saja kepada Allah supaya mereka diampuni yang menyebarkan berita itu," ujar komisioner KPU Evi Novida Ginting di gedung KPU, Jalan Imam Bonjol, Menteng, Jakarta Pusat, Jumat (10/5/2019). Evi mengatakan saat ini KPU dan jajarannya sedang berfokus mengawal rekapitulasi hasil Pemilu 2019.Dia mengatakan belum tahu apakah KPU akan menindaklanjuti masalah ini atau tidak."

Pada kutipan data di atas terdapat topik Petugas KPPS. Wartawan memilih topik tersebut yang secara tidak langsung telah memberikan dukungan kepada pemerintah atas terselenggaranya Pilpres 2019 serta menaruh kepercayaan terhadap kinerja teman-teman KPPS provinsi dalam tugas rekapitulasi nasional. Dari segi Partisipan, menjadi komisioner KPU, Evi Novida Ginting menjadi fokus utama sebagai partisipan. Dilihat dari segi nada pemberitaan wartawan banyak membicarakan tentang beredarnya berita hoax terkait petugas KPPS yang tewas diracun yang berefek dapat mengganggu konsentrasi rekapitulasi nasional.

Perspektif netral merupakan sudut pandang dalam melihat suatu peristiwa yang didasari oleh nilai-nilai keyakinan, ide-ide, dan pandangan netral atau tidak memihak siapapun. Perspektif netral didasari oleh sikap wartawan yang dapat menyesuiakan diri terhadap semua pihak yang terlibat dalam suatu peristiwa. Wartawan menyajikan berita dalam proposional dengan tidak mendukung salah satu pihak.Berikut ini adalah data yang menunjukan perspektif netral.

Pada data (T2/d) dengan judul (Jokowi Sangat Percaya TNI, Prabowo Lebih TNI dari Banyak TNI) menunjukan sikap wartawan yang netral.

"Capres Jokowi dan Prabowo Subianto sama-sama menegaskan komitmennya kepada

TNI.Jokowi menyebut dirinya menaruh penuh percaya pada TNI dan Prabowo menegaskan 
sudah mempertaruhkan nyawanya untuk TNI.Prabowo awalnya menyoroti anggaran pertahanan pemerintah Indonesia.Prabowo membandingkan dengan anggaran pertahanan yang dimiliki Singapura."

Pada kutipan data di atas terdapat topik Debat Capres Keempat Soal TNI.Wartawan memilih topik tersebut menunjukan perspektif netral, hal ini dikarenakan wartawan tidak memihak kepada siapapun yang terlibat dalam peristiwa pemberitaan tersebut.

Dari segi Partisipan, Joko Widodo dan Prabowo Subianto menjadi fokus utama sebagai partisipan. Dilihat dari segi nada pemberitaan wartawan banyak membicarakan tentang kepercayaan dan pandangan pada masing-masing pribadi dari Petahana Joko Widodo dan mantan Danjen Kopasus Prabowo mengenai TNI dalam debat capres putaran keempat Pilpres 2019.

Pada data (T4/d) dengan judul (Salah Input Data, 56 TPS di Kabupaten Malang Gelar Hitung Ulang)menunjukan sikap wartawan yang netral.

“Sebanyak 56 TPS di Kabupaten Malang menggelar hitung ulang.Langkah ini mengacu pada rekomendasi Bawaslu.Sebelumnya, TPS-TPS itu diketahui salah menginput data perolehan suara. Setelah ditelusuri dan dibuka pada lembar plano untuk dilakukan pengecekan, diketahui cara penghitungan perolehan suara tidak benar. Dan itu terjadi murni kesalahan dalam melakukan input data yang kemudian direkomendasi digelar hitung ulang. "Jadi murni salah dalam input data. Bisa karena faktor kelelahan dan kekeliruan petugas di PPS," ujar George."

Pada kutipan data di atas terdapat topik Input Data untuk menunjukan perspektif netral, hal ini dikarenakan wartawan tidak memihak kepada siapapun yang terlibat dalam peristiwa pemberitaan tersebut. Di sini wartawan banyak memberitakan tentang 56 TPS di Kabupaten Malang menggelar hitung ulang akibat salah input data.

Dari segi partisipan, Divisi Penindakan Pelanggaran Pemilu, Bawaslu Kabupaten Malang, George Da Silva menjadi fokus utama sebagai partisipan. Dilihat dari segi nada pemberitaan wartawan lebih banyak membicarakan tentang salah input data murni akibat faktor kelelahan atau kekeliruan petugas PPS sehingga hitung ulang suara pun digelar kembali.

Pada data (T5/d) dengan judul (SMS Bukan dari Setan Gundul Klaim BPN Menang) menunjukan sikap wartawan yang netral.

"Badan Pemenangan Nasional (BPN) Prabowo Subianto-Sandiaga Uno mengungkap asal usul munculnya klaim angka kemenangan 62\% di Pilpres 2019.Sejalan dengan itu, BPN juga membantah ada sosok setan gundul yang memberi data sesat soal angka kemenangan tersebut. Dirangkum detikcom, Sabtu (11/5/2019), ialah Prof Dr Laode Masihu Kamaluddin yang merupakan salah satu sosok yang ada di balik munculnya angka kemenangan $62 \%$ bagi paslon nomor urut 02 ini. Laode diperkenalkan oleh juru bicara BPN Prabowo-Sandi, Vasco Ruseimy, sebagai otak yang mengumpulkan data-data dari saksi dan relawan 02."

Pada kutipan data di atas terdapat topik Setan Gundul untuk menunjukan perspektif netral, ini dikarenakan wartawan tidak memihak kepada siapapun yang terlibat dalam peristiwa pemberitaan tersebut. Di sini wartawan banyak memberitakan tentang BPN yang mengungkap asal usul munculnya klaim angka kemenangan 62\% di Pilpres 2019 itu yakni berasal dari Prof Dr Laode.

Dari segi partisipan, Prof Dr Laode Masihu Kamaluddin menjadi fokus utama sebagai partisipan. Dilihat dari segi nada pemberitaan wartawan lebih banyak membicarakan tentang klaim angka kemenangan 62\% berasal dari metode hitung Dr Laode Masihu yang mengumpulkan data C1 dari banyak relawan.

\section{PENUTUP}

Berdasarkan hasil pembahasan di atas mengenai analisis bentuk ekspresi bahasa, analisis berita Pilpres 2019 di media detik.com menggunakan ketiga nilai dalam menggunakan pilihan kata, yaitu nilai eksperiensial, nilai relasional, dan nilai ekspresif. Dari ketiga nilai tersebut, pilihan kata banyak digunakan dengan nilai eksperiensial, sementara nilai ekspresif digunakan paling sedikit. Hal tersebut dapat dilihat dengan penggunaan 26 pilihan kata dengan nilai eksperiensial, 13 pilihan kata dengan nilai relasional, dan 8 pilihan kata dengan nilai 
ekspresif. Analisis perspektif terhadap wacana berita Pilpres 2019 pada media online detik.com tidak ditemukan data berkaitan dengan perspektif promasyarakat, 2 data yang propemerintah, dan 3 data netral.

\section{DAFTAR PUSTAKA}

Badara.(2012). Analisis Wacana: Teori, Metode, dan Penerapan Pada Wacana Medai. Jakarta: Kencana Prenada Media Group.

Eriyanto. 2001. Analisis Wacana. Yogyakarta: LKIS.

Januru, La. (2016). Analisis Wacana Black Campaign (Kampanye Hitam) pada Pilpres Tahun 2014 di Media Kompas, Jawa Pos, dan Kedaulatan Rakyat.Natapraja.Vol. 4 (2).Hlm. 181—194.

Kuswandari, A.H., dkk. (2017). Analisis Wacana: Representasi Pendidikan Indonesia pada Berita Online Detik.com. Metalingua.Vol 15 (2).Hlm. 145-152.

Mulyana, Deddy. (2009). Ilmu Komunikasi: Suatu Pengantar. Bandung: PT. Remaja Rosdakarya.

Setiawan, Budhi. 2012. Analisis Wacana. Salatiga: Widya Sari.

Sobur, Alex. (2009). Analisis Teks Media. Bandung: Rosdakarya.

Wati, Beti W. (2014). Analisis Wacana Kritis Berita Sosial dan Politik Surat Kabar Kedaulatan Rakyat.UNY: Skripsi.

Wijana dan Rohmadi, M. (2011).Analisis Wacana Pragmatik Kajian Teori dan Analisis.Surakarta: Yuma Pustaka.

Wijana, I Dewa P. (2015).Pengantar Semantik Bahasa Indonesia.Yogyakarta: Pustaka Pelajar. 